abused. Or, it may be, as Lord Camden, L.C.J. observed so long ago in striking down the general warrant, that: 46

It must have been the guilt or poverty of those upon whom such warrants have been executed, that deterred or hindered them from contending against the power of a Secretary of State... or such warrants could never have passed for lawful till this time.

We do not have in Canada, nor are we likely to get, an "exclusionary rule" i.e. a rule forbidding the production in evidence of the fruits of illegal searches. ${ }^{47}$ This may or may not be a good thing, but in its absence surely the least we can do is insist on judicial review and control of the powers of search and seizure. Judicial authority should always be a condition precedent to the entry and search of people's homes.

-John Faulkner*

46 Entick v. Carrington (1765) 2 Wils K.B. 275 at 292.

17 See however, the Report of the Canadian Committee on Corrections at 74.

- B.A. (Alta.) of the second year law class.

\title{
PANACEA FOR A JUDGMENT
}

There is a growing tendency by Canadian jurists to flesh out their reasons for judgment by listing a long collection of cases.

Some recent examples can be seen in the following: ${ }^{1}$

(1) In Barwick v. Targon ${ }^{2}$, Moorhouse, J. at the end of his judgment says this: ${ }^{3}$

Amongst the cases I have considered are the following:...

Then he lists twenty-three cases.

He concludes his judgment with these words, after which he lists an additional seven cases: ${ }^{4}$

The following Western cases have been considered:...

(2) In Reid v. Wilson et al. and two other actions ${ }^{5}$, Lacourciere, J. in his reasons for judgment says: ${ }^{6}$

I have been referred to and considered many authorities, and particularly the following:...

He then lists twenty-five cases and two torts textbooks (giving the page references in same).

(3) Riley, J. in Anders et al. v. Sim $^{7}$ uses the same technique. He says: ${ }^{8}$

1 This is not an attempt to make an exhaustive compilation of such instances. No doubt there have been instances in the past. See, for example, Goodman v. Wedlock (1905) 6 O.W.R. 777 at 780 where Britton, J. at the conclusion of his reasons for judgment says, "I have considered the cases of..." and then lists six cases. However he does go on to say that he feels that his decision is within the principle of those cases.

2 [1969] 1 O.R. 1 .

Id. at 6.

Id.

s [1970] 2. O.R. 760.

6 Id. at 767,768 .

7 (1970) 11 D.L.R. (3d) 366.

Bd. at 370. In Reliance Cordage Co. Ltd. v. Hetterly (1969) 5 D.L.R. (3d) 297 at 311, Bence, C.J.Q.B. says: "Other cases to which I have been referred on this point are..." He then mentions thirty-one cases with. out any comment whatsoever about them. 
Damages in this case are difficult, and I have been referred to the following cases: ...

He is more modest and lists only eleven cases (three of which are taken from a book on damages).

What are we to take out of these lists of collections of cases? Does it mean that all of these particular cases support the reasons for judgment; or that they are cited in support of some principle or principles upon which the judgment is based; or that they were submitted by counsel; or all or some of these assumptions?

Citation of a long list of cases in reasons for judgment can be effected with success. Mr. Justice Matas of the Manitoba Queen's Bench in Weiner v. Zoratti ${ }^{9}$ mentions five English and nine Canadian cases which defence counsel cited to him to show that there have been favourable comments about the decision in Wagon Mound (No. 1). ${ }^{10}$ In a sense one could say that such a list of cases, and in fact all of the lists of cases in the judgments referred to are nothing more than compilations taken from a standard work such as the Canadian Abridgment's Cases Judicially Considered (Carswell). To the extent that a list of cases is detailed in these judgments, it is certainly a time-saver for anybody wishing to do further reading in the same area.

Any day now we can expect to see reasons for judgment reading like this:

Trend, J. : Upon this application for dissolution of partnership I have considered all of the provisions of The Partnerships Act, and I have read Lindley on Partnership (12th ed., 949 pages) from cover to cover, and I must grant the application.

Furthermore, I have considered all sixty-five of the cases referred to by both counsel (herewith a list of cases follows).

In addition, I have read the relevant sections on partnership law in the Canadian Encyclopedic Digest, Canadian Abridgment (2nd ed.), Halsbury, Mews Digest, English and Empire Digest, Corpus Juris, and American Jurisprudence; and the learned articles on partnership in the journals of Harvard, Yale, Columbia and New York Universities, and in the Canadian Bar Review.

Order to go as asked. Costs in the cause."

Perhaps as an alternative to the technique of merely listing cases, there is some positive merit in the approach used by American jurists who make use of footnotes and appendices to cover materials in support of and with reference to their reasons for judgment; such techniques are standard and valuable in writing textbooks and learned articles, and could be utilized in judicial opinion writing.

On the other hand, it could be said that reciting a list of cases which the court has considered has the advantage of indicating to the reader the germane cases. But does it have even that advantage? If the court merely asserts that certain cases have been considered it does not necessarily follow that all of the enumerated cases are apposite.

If we presume that the itemized cases are in fact relevant to the issues before the court, then that in itself is of some merit. The court,

\footnotetext{
" (1970) 11 D.L.R. (3d) $; 98$.

"'" [1961] A.C. 3*4, [1961] 1 All F.R. 404.

"Another approach is where the judge says there has been much written about the area under discussion; hence he will not analyze or discuss it. In Kagina v. Wagner (unreported: Nova Scotia County Court, May 11. 197(1). Mclellan. J. in refusing to accept defence argument that section 19 of the Criminal Code (ignorance of the law is no excuse) is subject to th" overriding principle of mens rea. says: "Much has been written about this principle of English law which has been imported into the law of Canada. I do not propose to attempt herein an analysis of the cuse law and legal texts and articles on this subject." He does deal with defence argument, but on the basis of absence of mens rea.
} 
however, by the mere presentation of a long list of cases does not assist in indicating the degree of relevance, utility, and applicability of each of the cases. A recording such as that lacks meaningful and cogent vitality as part of judicial reasoning.

While the type of judgment rendered by Trend, J. may be too farfetched, nevertheless, if the judicial trend to catalogue cases in the perfunctory manner described continues, the day will shortly dawn when we will see Professor Lon Fuller's mythical judgments come to life. In his The Case of the Contract Signed on Book Day ${ }^{12}$ heard in the Supreme Court of Newgarth, 4305, Truepenny, C.J. says: ${ }^{13}$

\begin{abstract}
We are confronted in this case with the question whether a contract executed on Book Day is legally enforceable... There is furthermore an almost universal folk belief that a contract signed on that day is unenforceable. This view is probably shared by the majority of lawyers, who have never had occasion to look into the precedents on the subject.
\end{abstract}

\title{
And in the same case Keen, J. says to the world: ${ }^{14}$
}

Those who have followed the decisions of this court, and have witnessed my efforts to deal single-handedly with complex issues like that I have just discussed, will not have to be told that mine is not an easy position on the bench. With all the forces that surround me pulling in the opposite direction, it is no light undertaking to strive toward a clear conception of law and, with it, a clear and correct conception of the judicial office. It is with a sense of weariness that I review the attempts I have made in years gone by to enlist my brothers' aid in this undertaking. But I have resigned all hope of achieving that end. I know that my brother Tatting will continue to weave about every case presented to him an encircling filigree of irrelevant distinctions, my brother Foster will continue to make my task harder by doing everything he can to blur the distinction between law and morals, and my brother Handy, - well, the least that can be said of him is that one who does not believe in law can scarcely be expected to lend aid in arriving at a clear definition of law.

If the pressure of work is such that our jurists are compelled to buffer their decisions by outlining a list of cases which they state they have considered, then the time certainly has arrived when they require assistance. The Supreme Courts of Canada and Ontario have instituted and carried into effect programs whereby law clerks are assigned to judges, and possibly this program should be extended and made available throughout all of Canada for all judges starting at the district or county court level and above. The law clerk can relieve some of the pressure upon the jurist to research the law and aid in the writing of reasons for judgment.

If we are to have a bench which can make a valuable and significant impact upon the corpus of the law we have to think in terms of providing our jurists with adequate and suitable aids for the proper execution of their duties. ${ }^{15}$ Research assistance through and with the aid of law clerks is a simple and expedient device: hopefully its exten-

1: Fuller, The Problems of Jurisprudence 71 (temporary edition 1949).

1." ld. at 72 .

"Id. at 102.

"See Lord Wilberforce, Educating the Judges, (1969) 10 Journal of the Society of Public Teachers at Law 254 at 264.

The education of . potential judges must...take account of the far grenter width and variety of respon. sibility and interest which now falls to the judicial office, in its widest sense. Somewhere in the legal pool, and ultimately in the judicial pool, there must always be the probability of finding... every kind of technique, expertise, practical experience and social acquaintance. 
sion throughout the various levels of the judiciary may take place soon, and we will never have to plow through a Trend type of judgment.

Hugh W. Silverman, Q.C.*

- Professor, Faculty of Law, University of Windsor.

\section{SEIZURE-CONDITIONAL SALES-CONTRACTS-LIEN NOTES}

\section{Preliminary}

There would appear to be some disparity in practice in various jurisdictions in Alberta in process involving seizures under conditional sales contracts and lien notes. As a result a re-examination of procedures under the Seizures Act ${ }^{1}$ is desirable.

The conditional vendor stands in a position materially different from that of most other creditors as a result of the provisions of Section 19 of the Conditional Sales Act. ${ }^{2}$ A conditional vendor gets only one try at recovery of his debt, whereas an execution creditor may continue execution and debt recovery process until his debt is fully paid. Similarly, a chattel mortgagee ${ }^{3}$ may claim for deficiencies even after completing a seizure $e^{4}$ whereas a conditional vendor may not. As a result, solicitors acting for conditional vendors should be fully conscious of methods allowed under the Seizures Act to maximize returns from distress sales. ${ }^{5}$ The purpose of this article is to delineate and comment upon those methods.

The Seizures Act provides three ways in which sales can be conducted by the creditor personally. ${ }^{6}$ Generally, sales by public auction or tender, when made through the Sheriff's Office, do not produce the best medium for maximizing returns. Furthermore, the conditional vendor who in the normal course of his business deals in the type of chattels seized can generally make far more advantageous sales privately than can be made by Sheriff's "fire sale". So long as the debtor is protected from fraud or dishonesty (and the Seizures Act provides adequately for such protection), achieving private sales in the case of conditional sales contracts will normally give the creditor the best possible relief without detriment or loss to the debtor.

The procedure and remedies under the Act fall into two categories. One includes cases where no notice of objection is filed, and the other cases where there is objection.

i R.S.A. 1955 , c. 387.

2 R.S.A. 1955, c. 54, as amended by c. $15,1965$.

3 Except as to a chattel mortgagee governed by Section 19 of The Conditional Sales Contract Act.

4 Alec v. Higgins (1962) 41 W.W.R. 321; 33 D.L.R. (2d) 63, aff'ing 35 W.W.R. 378 (B.C.C.A.).

5 The need for such consideration bears not only on the remedies sought and granted, but upon the amount of redemption opportunity allowed to conditional sales contract debtors. For example, allowing such debtors long adjournments on applications for orders for removal and sale without providing for adequate assurance of payment of at least the probable depreciation of the chattels during the adjournment period can result in direct and irrecoverable loss to the creditor. It is suggested that solicitors seek, and the courts require, as a condition of any such sdjournment, that there be immediate or prompt payment on account of an amount sufficient to cover depreciation during the adjournment period.

- Sale under Section 30(1) (b), private sale by court leave under Section 29(1) and (6) and sale after delivery up to the creditor under Section 29(4) (b). 